EISSN: $2706-7947 \quad$ ISSN: 2077- 4613

DOI: 10.36632/mejas/2021.11.1.4

Journal homepage: www.curresweb.com

Pages: 28-42

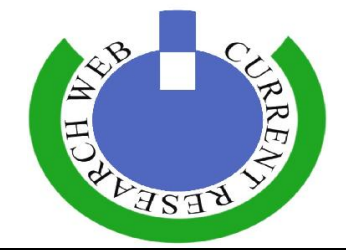

\title{
Nutritional Evaluation of Chia and Moringa Seeds Flour and Quality Characteristics of Fortified Cookies
}

\author{
Salem M.A. ${ }^{1}$, E.M. Elsharkasi ${ }^{2}$, M.E.A. El-Sayed ${ }^{1}$ and M. A. El-Bana $^{3}$ \\ ${ }^{I}$ Food Sci. and Tech. Dept., Fac. of Agric. Tanta Univ., Egypt. \\ ${ }^{2}$ General Organization for Export and Import Control (GOEIC), Egypt. \\ ${ }^{3}$ Food Tech. Res. Inst., Agric. Res. Center, Giza, Egypt
}

Received: 25 November $2020 \quad$ Accepted: 10 January $2021 \quad$ Published: 20 January 2021

\begin{abstract}
This study was carried out to investigate the utilization of defatted Chia seeds flour (DCSF) and defatted Moringa seeds flour (DMSF), as replacement of wheat flour at different levels (5, 10 and 15\%) to prepare cookies rich protein and minerals. The obtained results revealed that, DCSF and DMSF, are very rich in protein, ash and fiber compared with CSF, MSF and wheat flour $72 \%$. Wheat flour (72\%) contains lower values in all determined elements excepted for sodium compared to chia and moringa seeds in addition, moringa seeds had higher values of potassium, phosphorus, copper, than those of chia seeds. The total amino acids of chia and moringa seeds were $(56.97 \%)$ and $(79.13 \%)$ respectively. Furthermore, moringa seeds were rich in essential and non- essential amino acids than chia seeds. Total saturated fatty acid of moringa seeds oil were higher (23.43\%) than that of chia seeds oil (9.53\%).High amounts of extracted polyphenolic compounds by ethanol from chia and moringa seeds were (1.63 and $1.34 \mathrm{mg}$ gallic acid/g of DW) respectively. Moisture, crude protein, ash and crude fiber contents increased in cookies products in contrast, carbohydrates value decreased gradually with increasing the substitution levels of DCSF and DMSF. From the results of sensory evaluation, it should be noted that, fortification of DCSF and DMSF until $15 \%$ is acceptable for the sensory evaluation of cookies. Based on the obtained results, the new product of cookies contained DCSF and DCMF can be covered protein and minerals of nutritional needs of schoolchildren in developing countries and could be recommended as a food aid in institutional feeding programs for pupils in different school stages.
\end{abstract}

Keywords: Moringa seeds, Chia seeds, Minerals, Fatty acids; Amino acid profile; cookies

\section{Introduction}

Chia (Salvia hispanica L.) is an annual herbaceous plant belonging to the Lamiaceae (Mint) family (Ixtainaa et al., 2008).Chia seeds are a well-known food, their global production is renowned nowadays for their potential health properties. Recently, Lately, They were studied largely due to their rising success and recognition as a healthful food alternative (Capitani et al., 2017). The plant's seeds are a healthy source of polyunsaturated fatty acids (PUFA) at higher concentrations (equivalent to $83 \%$ of extracted oil), with high amounts of omega 3 fatty acids, dietary fiber $(34.4 \mathrm{~g} / 100 \mathrm{~g})$, total protein $(16.54$ $\mathrm{g} / 100 \mathrm{~g}$ ), and natural antioxidants (Giaretta et al., 2018). Chia seed has a high fat content of $25-40 \%$, out of which omega-3 and omega- 6 fatty acids constitute $68 \%$ and $20 \%$ of the total mass, respectively (Goyat et al., 2018). Chia protein contains high amounts of glutamic acid (123 g kg-1 raw protein), arginine (80.6 g kg-1 raw protein), and aspartic acid (61.3 $\mathrm{g} \mathrm{kg}-1$ raw protein). Its amino acid profile has no limiting factors in the adult diet, but threonine, lysine, and leucine were the limiting amino acids in a preschool child's diet. (Kulczynski et al., 2019). Moreover, chia seeds contain a high amount of phenolic compounds and natural antioxidants such as chlorogenic and caffeic acids, quercetin, and kaempferol (Ixtaina et al ., 2008)which protects consumers from unhealthy effects, such as certain

Corresponding Author: Salem M.A., Food Sci. and Tech. Dept., Fac. of Agric. Tanta Univ., Egypt. 
cardiovascular diseases, and certain types of cancer and providing vitamins and minerals(Craig and Sons, 2004).After oil extraction, residual chia meals included high amounts of fiber (19-23\%), protein (33.9-39.9\%), and antioxidant compounds which are comparable to other oil seeds used in the food industry (Marineli et al ., 2014).The cookies flavored by chia seed and date syrup have been enhanced by incorporating additional nutrients. Cookies fortified by Chia seeds are a healthy source of protein, fat, omega 3, and antioxidants (Chelladurai et al., 2019).

Moringa oleifera (also known as the "miracle plant") is one of West African regions's newest crops. The plant is entirely edible from leaves to roots. Moringa seeds contain significant sources of minerals (calcium, phosphorus and iron) and vitamins (A, B and C). It is rich in protein and fat but low in carbohydrates (Olushola, 2006). However, the protein, fat and mineral (especially magnesium) content of moringa seed has been reported to be significantly higher than that of moringa leave (Gopalakrishnanb et al., 2016).Moringa seeds has also been found to contain 36.18, 43.58, 3.73 and $16.51 \%$ protein, fat, ash, carbohydrate, respectively. In addition, it contain a profile of important minerals, and are a good source for protein, vitamins, $\beta$ - carotene, amino acids and various phenolics as well as antioxidants, anti-inflammatory nutrients and omega 3 and 6 fatty acid (Kasoloet al., 2010). The major saturated fatty acids present in the Moringa seeds are palmitic, stearic, and benic acids. Oleic acid is the main unsaturated fatty acid (67.9- 70.0ability during cooking and frying (Abdulkarim et al., 2005).

Historically, Moringa (Moring aoleifera L.) enriched nutritional supplement with major medical and therapeutic values.Literature reveals multipurpose applications of different parts of moringa such as leaves, flowers, pods, seeds and roots. Fruits of moringa are a major source of vitamin C, i.e., 120 $\mathrm{mg} / 100 \mathrm{~g}$ fresh sliced pods. Furthermore, It is used in functional and traditional foods, e.g., in making soups, weaning foods, amala, biscuits, bread, cake and yoghurt as well as cheese and has the ability to preserve foods. In various medicinal applications, it works as antioxidant, anticancer, antiinflammatory, antiulcer, anti hyperglycemic, anti diabetic and antimicrobial agent and in agricultural uses as animal feed, forage crop, (Masih et al., 2019).Cookies are the most common category among the numerous bakery products. Cookies are a dried food that having low moisture content.Cookies are nutritional, tasty, palatable, light weight and convenience. It has low moisture content than cakes and bread; cookies are safer from microbiological spoilage and have a long shelf-life. (Divya, 2012).

Cookies are widely accepted and consumed in many countries and therefore offer a valuable supplementation vehicle for nutritional improvement. Cookies have been suggested as a good way to use composite flours as they are ready-to-eat, provide a good source of energy, and are consumed widely throughout the world (Arshad et al., 2007).The term cookies or biscuits refers to a baked product generally containing the three main ingredients flour, sugar and fat, as they are called in many parts of the world. These are mixed together with other minor ingredients to form the dough (Mamat et al., 2010).

This study was carried out to study nutritional evaluation of Chia and Moringa seeds flour and to utilize of (DCSF) and (DMSF), in cookies processing as new food industries product in the Egyptian market rich protein and minerals.

\section{Materials and Methods}

\subsection{Materials}

Chia seed (Salvia hispanica L.) was purchased from a local market at El-Mansura, Al-Dakahlya Governorate, Egypt at season 2018-2019.

a- Moringa (Moringa oleifera) seeds was obtained from crop Research Institute, Agriculture Research Center, Sakha at the Governorate of Kafr El-Sheikh, Egypt, at season 2018-2019.

b- The seeds were cleaned manually and foreign matters, such as stones, dirt and broken seeds were removed. Afterwards, the seeds were packed in polyethylene bags and stored at $-18 \pm 2^{\circ} \mathrm{C}$ until used.

\section{Other ingredients:}

Wheat flours (72\%) were purchased from Delta Middle and West Milling Company, Tanta Egypt, sugar, shortening, baking powder, and whole egg were purchased from the local market of Tanta city at EL-Gharbia Governorate, Egypt. 


\section{Chemicals:}

All of chemicals used in this study were obtained from EL-Gomhouria pharmaceutical company,of Tanta city at EL-Gharbia Governorate, Egypt. All other chemicals were analytical grads.

\section{Chemical analysis:}

\section{Gross chemical composition and caloric value of samples:}

Moisture, ash, ether extract, crude protein and crude fiber content were determined according to the methods of A.O.A.C. (2005).Total and available carbohydrates were calculated by difference according to the methods of A.O.A.C. (2005).

The energy value was calculated according to James (1995). Energy value $\left(\mathrm{kcal} .100 \mathrm{~g}^{-1}\right)=(\mathrm{g}$ of protein $\times 4)+(\mathrm{g}$ of lipids $\times 9)+(\mathrm{g}$ of carbohydrates $\times 4)$.

Determination of minerals: samples were prepared for mineral determination according to the method of the A.O.A.C. (2005).

a- Phosphorus $(\mathrm{mg} / 100 \mathrm{~g})$ : Total phosphorus was determined by ascorbic acid technique using the colorimetric method that described by Murphy and Riley (1962).

b- Potassium and sodium ( $\mathrm{mg} / 100 \mathrm{~g})$ : Potassium and sodium contents of samples were estimated using flame photometer as given by Pearson (1976).

c- Iron, Magnesium, Manganese, Copper, Zinc and Calcium contents of samples were conducted using the atomic absorption spectrophotometer Perken Elmer Model 2180 and following the methods of Pearson (1976).

\section{Determination of amino acids:}

Fifty milligrams of the samples were mixed with $10 \mathrm{ml}$ of $6 \mathrm{~N}$ hydrochloric acid containing $50 \mu \mathrm{l}$ marcapto ethanol in heat-resistant tube. The tubes were sealed, heated in oven at $110^{\circ} \mathrm{C}$ for $24 \mathrm{~h}$., then cooled to room temperature and filtered through What man No.1 filter paper. Both tube and the precipitate were washed with distilled water. The washed water was added to the previous filtrate then completed to $25 \mathrm{ml}$ in a volumetric flask. Five $\mathrm{ml}$ of the filtrate were transformed to $25 \mathrm{ml}$ beaker and placed in a vacuum desiccator until dryness in presence of potassium hydroxide. The dried residue was dissolved in one $\mathrm{ml}$ of sodium citrate buffer (PH 2.2) and analyzed by (Beckman amino acid analyzer, Model 119 CL) as described by Sadasivam and Manickam (1992) method.

\section{Determination of Tryptophan:}

Tryptophan content of samples was determined colourimetrically after subjecting to alkaline hydrolysis as outlined by Blauth et al. (1963).

Computed protein efficiency ratio (C-PER): was calculated from the amino acid composition using the equation developed by Alsmeyer, (1974), C-PER $=-0.468+0.454$ (Leu) +0.105 (Tyr)

Computed biological value of protein (C-BV): Biological value of chia and moringa seeds protein were calculated according to Farag et al. (1996), using the following regression equation: $\mathrm{BV}(\%)=49.9+10.53(\mathrm{C}-\mathrm{PER})$.

\section{Extraction of total phenolic compounds (TPC):}

The prepared ground materials $(10 \mathrm{~g})$ of each sample were soaked in $100 \mathrm{ml}$ of each solvent (Ethanol, Ethyl acetate, Acetone and Diethyl ether) overnight in a shaker at room temperature according to Mohdaly et al. (2010). The extracts were filtrated through Whatman No.1 filter paper. The residues were re-extracted three time under the same conditions. The combined filtrates were evaporated under vacuum in a rotary evaporator below $40^{\circ} \mathrm{C}$. The extracts obtained after evaporation of organic solvents were stored $-18 \pm 2^{\circ} \mathrm{C}$ until further analysis.

\section{Determination of total phenolic compounds:}

Total phenolic compounds of the extracts were determined spectrophotometrically using Folinciocalteau reagent according to the method described by (Singleton et al., 1999) and used to estimate the phenolics-acid content using a standard curve prepared using gallic acid. 


\section{Determination of DPPH radical scavenging capacity:}

The 1,1-diphenyl-2-picrylhydrazyl (DPPH) assay (Lee et al., 2003) was performed with some modifications. The stock reagent solution $\left(1 \times 10^{-3} \mathrm{M}\right)$ was prepared by dissolving $22 \mathrm{mg}$ of DPPH in 50 $\mathrm{ml}$ of methanol and stored at $-20^{\circ} \mathrm{C}$ until use. The working solution $\left(6 \times 10^{-5} \mathrm{M}\right)$ was freshly prepared by mixing $6 \mathrm{ml}$ of the stock solution with $100 \mathrm{ml}$ of methanol. Antioxidants extracted from different samples were vortexed for $30 \mathrm{sec}$ with $3.9 \mathrm{ml}$ of DPPH solution and left for $30 \mathrm{~min}$ at room temperature , after which the absorbance at $515 \mathrm{~nm}$ was recorded. A absorbance of control without extract was also recorder. Scavenging activity was calculated as follows:

DPPH radical-scavenging activity $(\%)=($ A control - A sample $) /($ A control $) \times 100$

Where $\mathrm{A}$ is the absorbance at $515 \mathrm{~nm}$.

\section{Preparation of defatted chia and moringa seeds:}

Chia and moringa seeds mill weight was soaked for 48 hours at room temperature in an n-hexane solvent $\left(40-60^{\circ} \mathrm{C}\right)$, then filtered. This process was repeated three times using fresh solvent each time to extract most of the oils from the samples. Then the obtained solution was filtered and the solvent was removed by rotary evaporator according to Kahlon et al. (1992).The crude oil, obtained have a dark greenish color. While,the defatted chia and moringa were milled using a laboratory scale hammer mill. The resulting flour were sieved through a 60 -mesh screen and was kept in polyethylene bags and stored at $-18 \pm 2^{\circ} \mathrm{C}$ until used.

\section{Determination of Physical and Chemical Properties of Extracted Oils:}

Refractive index, Specific gravity, acid value, peroxide value, iodine value, saponification value and unsaponifiable matters of chia and moringa seeds oils were determined according the methods of A.O.A.C. (2005).

\section{Fatty acids composition of oils:}

The methyl esters were prepared using benzene: methanol: concentrated sulfuric acid (10:86:4) and the methylation process was carried out for one hour at $80-90{ }^{\circ} \mathrm{C}$ according to Stahl, (1967).Identification of the fatty acid methyl esters were performed by G.L.C A pyeunic'am Gas-Liquid Chromatography (model 4550) equipped with a flame ionization detector and coiled glass Colum $(1.6 \mathrm{~m}$ $\times 4 \mathrm{~mm}$ ) packed with $10 \%$ PEGA (polyethylene glycol adipate) supported on chromosorb W-AW 100200 mesh. Samples (1-1.5 ul) in to the column using ahamilton microsyringe. Gas chromatographic conditions used for isothermal analysis were column $190^{\circ} \mathrm{C}$ Flow rates: Hydrogen $33 \mathrm{ml} / \mathrm{min}$. nitrogen $30 \mathrm{ml} / \mathrm{min}$. and air $330 \mathrm{ml} / \mathrm{min}$. Peak areas were measured using specttophysic integrator. A.O.A.C. (2005).

\section{Preparation of the cookies:}

Method of Alobo (2001) was used to prepare the cookies samples. Blends containing 5, 10 and $15 \%$ of (DCSF) or (DMSF), were used as replacement of wheat flour ( $72 \%$ extraction). Dry ingredients (sugar, shortening, baking powder and sodium chloride) and eggs were blended with the flour blends and dough thoroughly kneaded Fig 1 . The dough was then placed on a cutting board, and then rolled out to achieve a suitable thickness and texture. Cookies cutter was used to cut the sheet of rolled dough into desired shapes and sizes, then baked in oven at $175 \pm 5^{\circ} \mathrm{C} 30 \mathrm{~min}$. The cooked cookies was allowed to cool at room temperature, packed and store into two lots. Initially, one lot was used for sensory evaluation and the other lot for chemical analysis.

\section{Sensory evaluation of cookies:}

A semi-trained panel of twenty members using ten-point hedonic-scale ratings for color, taste, odor, texture and overall acceptability in order to provide organoleptic characteristics for different repaired cookies, Watts et al. (1989). Liked extremely 9, Like very much 8, Liked moderately 7, Liked slightly 6, Neither liked nor disliked 5, Disliked slightly 4, Disliked moderately 3, Disliked very much 2 and Disliked extremely 1. 


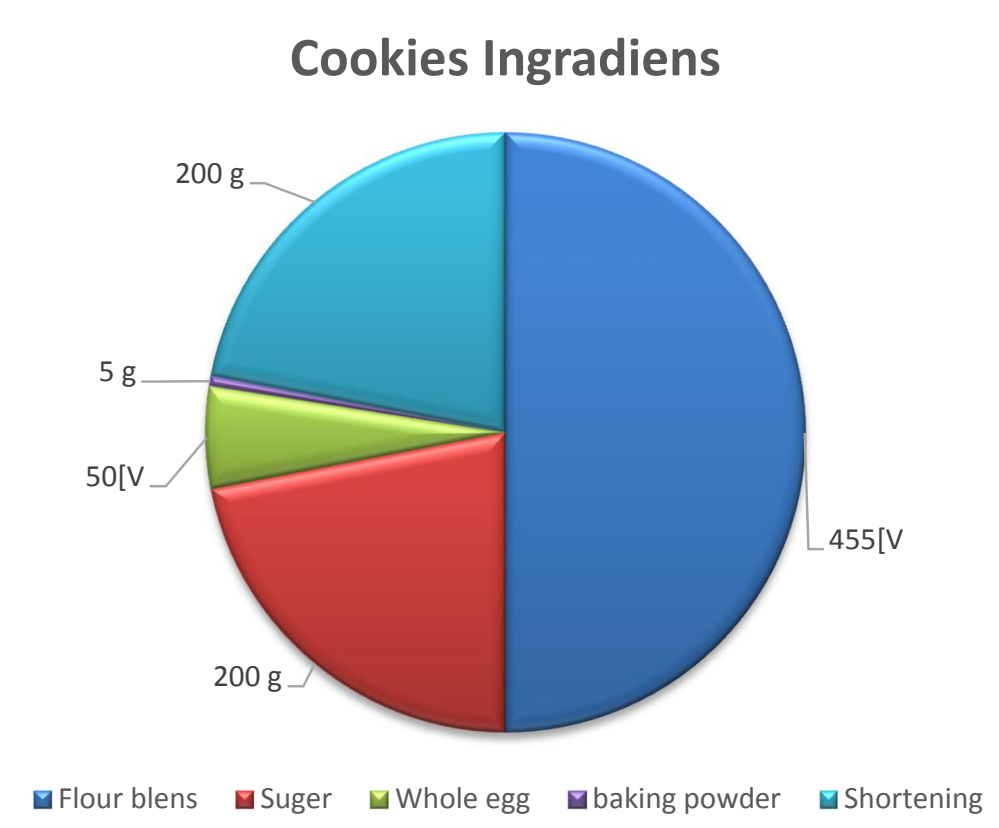

Fig. 1: Illustrates the composition of cookies

\section{Statistical analysis:}

Data were analyzed statistically using the analysis of variance and the means were further tested using DMART test outlined by Steel and Torrie (1980).

\section{Results and Discussion}

\subsection{Proximate composition:}

The gross chemical composition of chia (CSF), moringa seeds flour (MSF), defatted chia seeds flour (DCSF), defatted moringa seeds flour (DMSF), andwheat flour $72 \%$ are recorded in Table (1). The obtained results show that, DMSF contain a significant high content of crude protein $40.47 \%$ compared with that of MSF 30.67, DCSF $30.20 \%$, CSF 20.78 and wheat flour (72\%) $10.16 \%$.CSF contains highest content of ether extract (36.07\%) followed by MSF(34.99), DCSF 1.19, DCSF 1.02, then wheat flour $72 \%(0.95 \%)$. Furthermore, DCSF and DMSF, are very rich in protein, ash and fiber compared with CSF, MSF and wheat flour $72 \%$.

Table 1: Proximate chemical composition (\%), of raw samples (on dry weight basis).

\begin{tabular}{|c|c|c|c|c|c|}
\hline Component & $\begin{array}{l}\text { Chia } \\
\text { seeds }\end{array}$ & $\begin{array}{c}\text { Moringa } \\
\text { seeds }\end{array}$ & DCSF & DMSF & $\begin{array}{c}\text { WF } \\
(72 \%)\end{array}$ \\
\hline Moisture & $7.60 \pm 0.05^{b}$ & $7.07 \pm 0.11^{\mathrm{c}}$ & $7.2 \pm 0.22^{\mathrm{c}}$ & $6.7 \pm 0.25^{\mathrm{d}}$ & $11.22 \pm 0.13^{\mathrm{a}}$ \\
\hline Dry matter & $92.40 \pm 0.05^{\mathrm{c}}$ & $92.93 \pm 0.10^{\mathrm{b}}$ & $92.8 \pm 0.22^{b}$ & $93.3 \pm 0.25^{\mathrm{a}}$ & $88.78 \pm 0.13^{\mathrm{d}}$ \\
\hline Protein & $20.78 \pm 0.20^{\mathrm{c}}$ & $30.67 \pm 0.50^{\mathrm{b}}$ & $30.20 \pm 0.25^{b}$ & $40.47 \pm 0.29^{\mathrm{a}}$ & $10.16 \pm 0.14^{\mathrm{d}}$ \\
\hline ether extract & $36.07 \pm 0.7^{\mathrm{a}}$ & $34.99 \pm 0.4^{\mathrm{b}}$ & $1.19 \pm 0.24^{\mathrm{c}}$ & $1.02 \pm 0.21^{\mathrm{c}}$ & $0.95 \pm 0.16^{\mathrm{c}}$ \\
\hline Ash & $4.81 \pm 0.04^{\mathrm{c}}$ & $4.29 \pm 0.10^{\mathrm{d}}$ & $8.2 \pm 0.26^{\mathrm{a}}$ & $7.84 \pm 0.30^{\mathrm{b}}$ & $0.65 \pm 0.15^{\mathrm{e}}$ \\
\hline Crud fiber & $26.70 \pm 0.9^{b}$ & $9.70 \pm 0.07^{\mathrm{d}}$ & $40.54 \pm 0.25^{\mathrm{a}}$ & $19.87 \pm 0.22^{\mathrm{c}}$ & $0.78 \pm 0.15^{\mathrm{e}}$ \\
\hline Total carbohydrats & $38.34 \pm 0.5^{\mathrm{d}}$ & $30.05 \pm 0.4^{\mathrm{e}}$ & $60.41 \pm 0.0 .75^{\mathrm{b}}$ & $50.67 \pm 0.80^{c}$ & $88.24 \pm 0.45^{\mathrm{a}}$ \\
\hline Available carbohydrats & $11.64 \pm 0.8^{\mathrm{d}}$ & $20.35 \pm 0.7^{\mathrm{c}}$ & $19.87 \pm 1.0^{\mathrm{c}}$ & $30.8 \pm 1.02^{b}$ & $87.46 \pm 0.60^{\mathrm{a}}$ \\
\hline Total energy (Kcal/100) & $561.11 \pm 0.52^{\mathrm{a}}$ & $557.79 \pm 081^{\mathrm{b}}$ & $373.15 \pm 0.16^{\mathrm{d}}$ & $373.74 \pm 0.15^{\mathrm{d}}$ & $402.15 \pm 0.20^{\mathrm{c}}$ \\
\hline
\end{tabular}

Each value was an average of three determinations.

Values followed by the same letter in row are not significantly different at $\mathrm{p} \leq 0.05$.

WF $72 \%$ : wheat flour $72 \%$, DCSF: defatted chia seeds flour,

DMSF: defatted moringa seeds flour.

This means, the DCSF, DMSF when is added to bakery products would be improved their protein and minerals content. Data in this respect were in agreement with the findings of numerous of 
investigators (Ogunsina et al., 2010; Amato et al., 2015; Fernandes and Salas-Mellado, 2017; Hammad, 2018; Mohammed, 2019 and Salama, 2019)

\subsection{Minerals content:}

Minerals or elements play an important role in human nutrition, some are essential for much component as hem for blood(National Academy of Sciences, 2001). The data presented in Table (2)observed that, wheat flour (72\%)) contains lower values in all determined elements excepted for Sodium compared to chia and moringa seeds .

Apparent also from the same Tables that, the chia seeds had high levels of calcium $(621 \mathrm{mg} / 100 \mathrm{~g})$, magnesium (290.25 mg/100g), sodium (22.4 mg/100g), iron (7.7 mg/100g) and Zinc (5.35 mg/100g), than those of moringa seeds. While moringa seeds had higher values of potassium, phosphorus, copper, than those of chia seeds. In addition, the iron content of chia seeds is higher five times than that of wheat flour. The iron is important for the schoolchildren, which mostly needs more iron to avoid the anemia especially in developing countries. The results indicated that, the chia and moringa seeds when added to bakery products would improve their minerals content. These results are supported by European Food Safety Authority (2009), El-Massry et al. (2013), Ullah et al. (2015), Salha (2018), Mohammed (2019) and Salama (2019).

Table 2: Mineral contents (mg/100g) of chia, moringa seeds and wheat flour $72 \%$.

\begin{tabular}{lccc}
\hline Minerals & Chia seeds & Moringa seeds & Wheat flour 72\% \\
\hline Potassium(K) & $470.00 \pm 3.6^{\mathrm{b}}$ & $840.90 \pm 4.9^{\mathrm{a}}$ & $140.0 \pm 2.1^{\mathrm{c}}$ \\
Sodium(Na) & $22.40 \pm 0.25^{\mathrm{b}}$ & $7.20 \pm 0.08^{\mathrm{c}}$ & $25.89 \pm 0.27^{\mathrm{a}}$ \\
Calcium(Ca) & $621.00 \pm 4.2^{\mathrm{a}}$ & $254.11 \pm 2.7^{\mathrm{b}}$ & $37.0 \pm 0.34^{\mathrm{c}}$ \\
Phosphorus(P) & $645.00 \pm 4.5^{\mathrm{b}}$ & $721.40 \pm 4.7^{\mathrm{a}}$ & $316.0 \pm 3.2^{\mathrm{c}}$ \\
Copper(Cu) & $0.80 \pm 0.04^{\mathrm{b}}$ & $1.10 \pm 0.06^{\mathrm{a}}$ & $0.004 \pm 0.001^{\mathrm{c}}$ \\
Zinc(Zn) & $5.35 \pm 0.09^{\mathrm{a}}$ & $4.57 \pm 0.07^{\mathrm{b}}$ & $2.12 \pm 0.05^{\mathrm{c}}$ \\
Manganese(Mn) & $1.40 \pm 0.02^{\mathrm{a}}$ & $1.30 \pm 0.009^{\mathrm{b}}$ & $0.03 \pm 0.001^{\mathrm{c}}$ \\
Magnesium(Mg) & $290.25 \pm 2.8^{\mathrm{a}}$ & $281.00 \pm 2.7^{\mathrm{b}}$ & $132.0 \pm 2.03^{\mathrm{c}}$ \\
Iron(Fe) & $7.70 \pm 0.09^{\mathrm{a}}$ & $6.90 \pm 0.06^{\mathrm{b}}$ & $1.60 \pm 0.008^{\mathrm{c}}$ \\
\hline
\end{tabular}

Each value is an average of three determinations \pm standard deviation.

Values followed by the same letter in rows are not significantly different at $\mathrm{P}<0.05$.

\subsection{Amino acids composition:}

The nutritive value of food, especially protein mostly would depend not only on its amino acids profile in general but also on the quantities of the essential amino acids content in particular (Afify et al., 2012). Amino acids composition of chia and moringa seeds are given in Table (3). The results show that, the moringa seeds were rich in essential and non- essential amino acids than chia seeds. The total amino acids of chia and moringa seeds were (56.97\%) and (79.13\%) respectively.

As for essential amino acids, it could be observed that, Leucine was the dominant acid in chia seeds that recorded (3.97\%), followed by Lysine (3.10\%).Furthermore, Leucine was the dominant acid in moringa seeds that recorded (4.63\%) followed by phenylalanine $(4.31 \%)$.

Meanwhile, tryptophan was the lowest amino acid in chia and moringa seeds that recorded $(0.42$ and $0.10 \%$ respectively). These result agreement with Hammad (2018); Mohammed (2019) and Salama (2019) they reported that, Leucine was the dominant acid in chia and moringa seeds. Concerning nonessential amino acids reflected that, glutamic acid was the highest amino acid among all of the other acids in chia and moringa seeds that recorded (11.56 and $16.46 \%$ respectively). Arginine was the second level in both chia and moringa seeds that recorded (6.76 and $11.78 \%$ respectively), followed by aspartic acid and alanine in both chia and moringa seeds. These results agreement with Hammad (2018); Mohammed (2019) and Salama (2019) they found that, glutamic acid was the highest concentration in chia and moringa seeds. Furthermore, glutamic acid considered an important amino acid in the diet. It is able to modulate imm-regulatory response and enhances athletic performance. Also, arginine plays role in preventing heart diseases (Timilsena et al., 2017).

The quality of proteins as source of amino acids can usually be adequately assessed by comparison with the recommended pattern of essential amino acids. Moringa and chia seed flours had lower total essential amino acids than the FAO/WHO (1973) reference pattern. Meanwhile, Metheonine + Cycteine were higher amino acid in chia and moringa seeds comparison with the FAO/WHO (1973) 
recommended pattern. Furthermore, Moringa seeds reported higher Phenylalanine+ Tyrosine content, than the FAO/WHO (1973) reference pattern. These results showed that Moringa and chia seeds could be used to complement cereal proteins (MuneMune, et al., 2011). Apparent also from the same Table that, the lower (C-PER) and (B.V.) values were recorded in chia seeds compared with moringa seeds. Our findings are coincided with those of (Hammad 2018).

Table 3: Amino acids profile (\%) of chia and moringaseeds.

\begin{tabular}{lccc}
\hline Amino acids & Chia seeds & Moringa seeds & FAO/WHO (1973) \\
\hline Valine & 2.23 & A-Essential amino acid & \\
Leucine & 3.97 & 3.49 & 5.0 \\
Isoleucine & 2.01 & 4.63 & 7.0 \\
Metheonine & 1.86 & 2.28 & 4.0 \\
Cycteine & 1.89 & 1.92 & \\
Metheonine+Cycteine & 3.75 & 2.89 & 3.5 \\
Therionine & 2.13 & 2.81 & 4.0 \\
Phenylalanine & 2.89 & 2.83 & \\
Tyrosine & 2.11 & 4.31 & 6.0 \\
Phenylalanine+ Tyrosine & 5.0 & 1.93 & 5.50 \\
Lysine & 3.10 & 6.24 & 1.0 \\
Tryptophan & 0.42 & 2.25 & \\
Total Essential amino acid & 22.61 & 26.10 & \\
& & B-Non-essential amino acid & \\
Glycine & 2.34 & 4.13 & \\
Alanine & 2.68 & 4.32 & \\
Serine & 2.24 & 3.96 & \\
Aspartic acid & 4.89 & 4.86 & \\
Glutamic acid & 11.56 & 16.46 & \\
Proline & 2.13 & 4.67 & \\
Arginine & 6.76 & 11.78 & \\
Histidine & 1.76 & 2.32 & \\
Total Non-essential amino acid & 34.36 & 52.5 & \\
Total amino acid & 56.97 & 79.13 & \\
C-PER & 1.61 & 1.84 & \\
BV & 66.85 & 69.27 & \\
\hline
\end{tabular}

Tryptophan was determined colorimetrically.

C-PER: The computed protein efficiency ratio..

B.V: Biological value

3.4. Effect of using different solvents on total polyphenol extracted from chia and moringa seeds: Phenolics are antioxidants, and there is a general belief that the phenolics present in plant food contribute to prevent the oxidative damage that is implicated in a range of diseases, including cancer, cardiovascular diseases and aging (Scalbert et al., 2005).

Total polyphenols extracted from chia and moringa seeds are givenin Table (4). The data indicate that, ethanol was the best solvent for extracting polyphenols from chia and moringa seeds. High amounts of extracted polyphenolic compounds by ethanol from chia and moringa seeds were 1.63 and 1.34 (mg gallic acid/g of DW), respectively, comparing with other solvents. These results are similar with that obtained by Su et al. $(2007)$ They revealed that, methanol and ethanol were better $(\mathrm{P}<0.05)$ than the ethyl acetate and acetone for extracting phenolic compounds owing to their higher polarity and good solubility for phenolic components from plant materials. The data in the same Table indicated that, chia seed contained highest amounts of polyphenolic compounds with all using solvents comparing with moringa seeds. These result agreement with Marineli et al. (2014) and Mohammed (2019).

Antioxidants are compounds that act against free radicals in human bodies. High levels of free radicals cause oxidative stress, which may contribute to chronic diseases like heart disease and type 2 diabetes (Rodrigo et al., 2011).Apparent also from this Table that, ethanol was the best solvent for antioxidant activity from chia and moringa seeds. High percentage of DPPH inhibition of polyphenolic compounds by ethanol from chia and moringa seeds were $94.63 \%$ and $91.34 \%$ respectively,comparing 
with other solvents due to these extract may contain many phenolic compounds that contributed of antioxidant activity. Meanwhile, diethyl ether recorded the lowest value of antioxidant activity (DPPH) in chia and moringa seeds comparing with other solvents. These findings are in close agreement with previous findings of Fitriana et al., (2016) and Reyes et al., (2008).

Table 4: Effect of using different solvents on total polyphenol contents and antioxidant activity by (DPPH) extracted from chia and moringa seeds.

\begin{tabular}{ccccc}
\hline $\begin{array}{c}\text { Extraction } \\
\text { solvent }\end{array}$ & \multicolumn{2}{c}{$\begin{array}{c}\text { Total polyphenols } \\
\text { (mg gallic acid/g of DW) }\end{array}$} & \multicolumn{2}{c}{$\begin{array}{c}\text { DPPH } \\
\text { (\%) }\end{array}$} \\
\cline { 2 - 5 } & Chia seed & Moringa seed & Chia seeds & Moringa seeds \\
\hline Ethanol & $1.63 \pm 0.34^{\mathrm{Aa}}$ & $1.34 \pm 0.25^{\mathrm{Ab}}$ & $94.63 \pm 0.26^{\mathrm{Aa}}$ & $91.34 \pm 0.66^{\mathrm{Ab}}$ \\
Acetone & $0.91 \pm 0.09^{\mathrm{Ca}}$ & $0.79 \pm 0.03^{\mathrm{Cb}}$ & $71.43 \pm 0.09^{\mathrm{Ca}}$ & $66.84 \pm 0.78^{\mathrm{Cb}}$ \\
Ethyl acetate & $1.16 \pm 0.11^{\mathrm{Ba}}$ & $1.08 \pm 0.11^{\mathrm{Bb}}$ & $90.00 \pm 0.71^{\mathrm{Ba}}$ & $85.82 \pm 0.59^{\mathrm{Bb}}$ \\
Diethyl ether & $0.69 \pm 0.17^{\mathrm{Da}}$ & $0.55 \pm 0.07^{\mathrm{Db}}$ & $63.32 \pm 0.94^{\mathrm{Da}}$ & $53.89 \pm 0.76^{\mathrm{Db}}$ \\
\hline
\end{tabular}

Each value is an average of three determinations \pm standard deviation.

In column means with the same capital superscript letters are not significantly different at $\mathrm{p} \leq 0.05$.

In row means with the same small superscript letters are not significantly different at $\mathrm{p} \leq 0.05$.

DPPH = 1,1-diphenyl-2-picrylhydrazyl.

\subsection{Some Physical and chemical characteristics of oils extracted from chia and moringa seeds:}

Results in Table(5) indicated that, the refraction index, relative density, acid value, peroxide value, iodine index, saponification value and unsaponifiable matter in chia were 1.476 at $25^{\circ} \mathrm{C}, 0.830$ at $20^{\circ} \mathrm{C}$, $0.70 \mathrm{mg} \mathrm{KOH} / \mathrm{g}$ oil, $0.54 \mathrm{meqo}^{2} / \mathrm{kg}$ oil, $194.28 \mathrm{gI}_{2} / 100 \mathrm{~g}$ oil, $186.08 \mathrm{mg} \mathrm{KOH} / \mathrm{g}$ oil, $0.883 \mathrm{~g} / \mathrm{kg}$. while moringa oil were 1.462 at $25^{\circ} \mathrm{C}, 0.860$ at $20^{\circ} \mathrm{C}, 1.93 \mathrm{mg} \mathrm{KOH} / \mathrm{g}$ oil, $0.71 \mathrm{meqo}^{2} / \mathrm{kg}$ oil, $68.03 \mathrm{gI}_{2} / 100 \mathrm{~g}$ oil, $180.25 \mathrm{mgKOH} / \mathrm{g}$ oil and $0.863 \mathrm{~g} / \mathrm{kg}$ of the same characteristics respectively. From the obtained results, it could be noticed that, the chia oil had the highest saponification value, Unsaponifiable matter and iodine index, while moringa seed oil contained higher acid value, peroxide value. Because chia and moringa seed oil contains high amount of unsaturated fatty acids its relative density was high. The relative density of chia and moringa seed oil was similar with that of sunflower $(0.91)$, safflower $(0.92)$ and soy $(0.919)$ oils at $20^{\circ} \mathrm{C}$ (Segura-Campose et al., 2014).

The saponification value of chia and moringa seeds oil was also similar with that of sunflower (188-194 mg KOH/g oil), soybean oil (189-195 mg KOHg oil). It means also that, chia and moringa seed oil contains lower proportion of short chain fatty acids like such oils. It is also expected the rise of iodine value of chia seed oil due to its content of unsaturated fatty acids particularly linolenic one, up to $60 \%$. Therefore, this type of oil has higher iodine value than linseed or flaxseed oil (189), sunflower oil (141) (Timilsena et al., 2017).

Table 5: Some Physical and chemical properties of chia and moringa oils.

\begin{tabular}{lcc}
\hline Property & Chia oil & Moringa oil \\
\hline Refraction index $\left(\mathbf{2 5}^{\circ} \mathbf{c}\right)$ & $1.476 \pm 0.03^{\mathrm{a}}$ & $1.462 \pm 0.01^{\mathrm{b}}$ \\
Relative density at $\left(\mathbf{2 0}^{\circ} \mathbf{c}\right)$ & $0.830 \pm 0.02^{\mathrm{b}}$ & $0.860 \pm 0.01^{\mathrm{a}}$ \\
Acid value $(\mathbf{m g K O H} / \mathbf{g}$ oil) & $0.70 \pm 0.01^{\mathrm{b}}$ & $1.93 \pm 0.02^{\mathrm{a}}$ \\
Peroxide value(meq $\mathbf{~}^{\mathbf{2}} / \mathbf{K g}$ oil & $0.54 \pm 0.02^{\mathrm{b}}$ & $0.71 \pm 0.02^{\mathrm{a}}$ \\
Iodine index $\left(\mathbf{g}\right.$ of $\mathbf{I}_{2} / \mathbf{1 0 0 g}$ oil) & $194.28 \pm 0.15^{\mathrm{a}}$ & $68.03 \pm 0.06^{\mathrm{b}}$ \\
Saponification value $(\mathbf{m g ~ K O H} / \mathbf{g}$ oil & $186.08 \pm 0.26^{\mathrm{a}}$ & $180.25 \pm 0.31^{\mathrm{b}}$ \\
Unsaponifiable matter(g/kg) & $0.883 \pm 0.01^{\mathrm{a}}$ & $0.863 \pm 0.01^{\mathrm{b}}$ \\
\hline
\end{tabular}

Each value is an average of three determinations \pm standard deviation.

Values followed by the same letter in rows are not significantly different at $\mathrm{P}<0.05$.

Refractive index is one of important physical parameter which used the identification of fats and oil because it could be used for the estimation the degree of saturation of oils. The refraction index value in chia and moringa seed oil was similar that reported by Codex Stan 210 (2003) in sunflower (1.461), safflower (1.467) and soy (1.466) oils at $40^{\circ} \mathrm{C}$. According to Alvarado and Aguilera (2001), the refraction index is dependent on the analysis temperature and unsaturation contents of the fatty acids. They establish that high analysis temperatures showed lower refraction index values, and high unsaturation content is related to high refraction index values. Generally chia and moringa seed oils 
were similar refraction index, unsaponifiable matter and relative density. These results confirmed with (Segura-Camposeet al., 2014, Timilsena et al., 2017 and Mohammed, 2019). They found that, crude chia seed oil contained $0.70-2.54 \mathrm{mg} \mathrm{KOH} / \mathrm{g}$ oil acid value, $1.64-4.33 \mathrm{meq} \mathrm{o} / \mathrm{kg}$ oil peroxide value, $1.47-1.48$ refraction index at $25^{\circ} \mathrm{C}, 189.1-222.66 \mathrm{mg} \mathrm{KOH} / \mathrm{g}$ oil saponification value, $0.68-1.27 \mathrm{~g} / \mathrm{kg}$ unsaponifiable matter, $194.7-215 \mathrm{gI}_{2} / 100 \mathrm{~g}$ oil iodine index and $0.923-0.924$ relative density at $20^{\circ} \mathrm{C}$. Also,(Vibhuteet al., 2015;Saad 2015 and Pereira et al.,2016).They found that, moringa seed oil contained $1.35-2.73 \mathrm{mg} \mathrm{KOH} / \mathrm{g}$ oil acid value , $0.59-3.10 \mathrm{meq} \mathrm{o}^{2} / \mathrm{kg}$ oil peroxide value , $1.45-1.47$ refraction index at $25^{\circ} \mathrm{C}, 164.09-191.2 \mathrm{mg} \mathrm{KOH} / \mathrm{g}$ oil saponification value, $0.59-0.84 \mathrm{~g} / \mathrm{kg}$ unsaponifiable matter, $65.6-86.7 \mathrm{gI}_{2} / 100 \mathrm{~g}$ oil iodine index and $0.88-1.05$ relative density at $20^{\circ} \mathrm{C}$.

\subsection{Fatty acids composition of chia and moringa seeds oil:}

Fatty acids composition of chia and moringa seed oils are presented in Table (6). Data showed that, moringa seeds oil had stearic acid, lignoceric acid and behenic acid more than that of chia seeds oil, but palmitic acid in chia seeds oil was higher than of moringa seeds oil. Generally, total saturated fatty acid of moringa seeds oil were higher (23.43\%) than that of Chia seeds oil (9.53\%).

Among the saturated fatty acids, the highest concentration was Palmitic acid (7.23\%) in chia seeds oil meanwhile, behenic acid $(6.77 \%)$ was the highest in moringa seeds oil. As for unsaturated fatty acids, it could be cleared that, chia seeds oil had higher linoleic acid and linolenic acid than those of moringa seeds oil, but moringa seeds oil had higher amount of oleic acid and vaccenic acid than that of chia seeds oil. Generally, chia seeds oil contained higher amounts of unsaturated fatty acids $(89.72 \%)$ than that of moringa seeds oil (75.68\%). This is due to that,linolenic acid $(63.89 \%)$ and linoleic acid $(18.89 \%)$ were the most abundant fatty acids in chia seeds oil, whereas oleic $(66.66 \%)$ acid was the major components of moringa seed oil. These results agreement with Salama, (2019) reported that, the major saturated fatty acids in moringa seeds oil was behenic acid $(6.49 \%)$ followed by palmitic acid $(5.90 \%)$, while the major components of unsaturated fatty acid was oleic acid $(65.68 \%)$ followed by vaccenic acid (6.15\%).Furthermore, Ixtaina et al. (2012)and Mohammed, (2019) they found that,linolenic acid $(64.56-62.93 \%)$, linoleic acid (16.77 - 20.67\%), palmitic acid $(7.15-6.3 \%)$ and stearic $(1.78-1.31 \%)$ of chia seeds oil.

Table 6: Fatty acids composition of chia and moringa seeds oil.

\begin{tabular}{|c|c|c|}
\hline r & \begin{tabular}{cc|} 
Constituent & $\begin{array}{c}\text { Chia } \\
\text { seeds oil }\end{array}$ \\
\end{tabular} & $\begin{array}{l}\text { Moringa } \\
\text { seeds oil }\end{array}$ \\
\hline LauricC12:0 & 0.22 & - \\
\hline Myristic C14:0 & 0.03 & 0.09 \\
\hline Palmitic C16:0 & 7.23 & 6.45 \\
\hline Margaric C17:0 & 0.06 & 0.09 \\
\hline Stearic C18:0 & 1.76 & 5.31 \\
\hline ArachidicC20:0 & - & 3.43 \\
\hline Behenic C22:0 & 0.09 & 6.77 \\
\hline LignocericC24:0 & 0.14 & 1.29 \\
\hline Total saturated fatty Acids(SFA) & 9.53 & 23.43 \\
\hline Tetradecanoic C14:1 & 0.6 & - \\
\hline Palmitoleic C16:1 & 0.09 & 1.36 \\
\hline Oliec C18:1 n9 & 6.22 & 66.66 \\
\hline Elaidic C18:1 n9 & 0.03 & 0.16 \\
\hline Vaccenic C18:1 n7 & - & 5.43 \\
\hline Linoleic C18:2 n6 & 18.89 & 0.49 \\
\hline Linolenic C18:3 n3 & 63.89 & 0.15 \\
\hline Gondoic C20:1 & - & 1.34 \\
\hline Erucic C22:1 & - & 0.09 \\
\hline Total unsaturated fatty acids (USFA) & 89.72 & 75.68 \\
\hline Saturated to unsaturated FA ratio & 1: 9.4 & $1: 3.2$ \\
\hline Total(FA) & 99.25 & 99.11 \\
\hline
\end{tabular}

\subsection{Chemical composition of cookies:}

The results of chemical composition of cookies made from different levels of defatted chia seeds flour (DCSF) and defatted moringa seeds flour (DMSF) were recorded in Table (7). The obtained results 
manifested that, the Moisture, crude protein, ash and crude fiber contents increased. while, carbohydrates value decreased gradually with increasing the substitution levels of DCSF and DMSF. These results are in a harmony with the findings of Peiretti and Gai, (2009) and Olosunde et al. (2014) who reported that, supplementation with moringa seed flour could also improve the protein contents of kunu-zaki as it has been found to contain essential nutrients needed the body. Also, Chinma et al. (2013) mentioned that, the high protein and mineral contents of moringa seeds and its lower carbohydrate content compared with wheat flour, this food product will be beneficial to the nutrition. Furthermore, Barrientos et al. (2012); Divyashree et al. (2016) and Mesias et al. (2016) found that, adding chia seed flour in wheat based biscuit formulation enhanced the nutritional quality of this product, increasing protein, dietary fiber, antioxidants and polyunsaturated fatty acids. The latter component accelerates lipid oxidation in biscuits enriched with high amount of chia seed and that reducing its shelf life. From the same Table, there were significant differences between control and substitution cookies at different levels of DCSF and DMSF in moisture content. The moisture contents ranged between $6.51 \%$ in control to 8.70 and $7.80 \%$ in substitution cookies with $15 \%$ DCSF and DMSF. The increased moisture content can be explained by the higher content of protein which also increases the water binding capacity of dough with higher levels of DCSF and DMSF. It is also reported that, moisture content of cookies increased resulted in addition of defatted maize germ cookies flour (DMGCF) (Farahat et al., 2020). Apparent also from the same Table that, substitution of DCSF and DMSF to wheat flour lead to increased significantly protein content from $11.60 \%$ in control to 14.71 and $15.91 \%$ in cookies substitution with $15 \%$ DCSF and DMSF respectively. The protein content of the substitution cookies was increased by increasing the concentrations of substitution DCSF and DMSF. This increment may be due to the DCSF and DMSF were high protein content as compared to the wheat flour. Data of the present study are in agreement with those found by Anwar et al. (2006); Ogunsina et al. (2010); Abiodun et al. (2012); Vuksan et al. (2017) and Goyat et al. (2018). Therefore, defatted chia and moringa seeds had tendency to improve the protein contents cookies.

Table 7: Chemical composition (\% on dry weight basis) of cookies made of different substitution levels of defatted chia and moringa seeds flour.

\begin{tabular}{cccccccccc}
\hline Parameter & $\begin{array}{c}\text { Moisture } \\
\text { \% }\end{array}$ & $\begin{array}{c}\text { Dry } \\
\text { matter } \\
\text { \% }\end{array}$ & $\begin{array}{c}\text { Protein } \\
\text { \% }\end{array}$ & $\begin{array}{c}\text { Ether } \\
\text { Extract } \\
\text { \%okies }\end{array}$ & $\begin{array}{c}\text { Con } \\
\text { \% }\end{array}$ & $\begin{array}{c}\text { Fiber } \\
\%\end{array}$ & $\begin{array}{c}\text { T.C } \\
\%\end{array}$ & $\begin{array}{c}\text { A.C } \\
\%\end{array}$ & $\begin{array}{c}\text { Total } \\
\text { Energy } \\
\text { kcal/100g }\end{array}$ \\
\hline Contol & 6.51 & 93.49 & 11.60 & 8.10 & 0.99 & 1.90 & 77.41 & 75.51 & 428.94 \\
& $\pm 0.25^{\mathrm{e}}$ & $\pm 0.25^{\mathrm{a}}$ & $\pm 0.29^{\mathrm{f}}$ & $\pm 0.22^{\mathrm{a}}$ & $\pm 0.19^{\mathrm{c}}$ & $\pm 0.12^{\mathrm{f}}$ & $\pm 0.82^{\mathrm{a}}$ & $\pm 0.94^{\mathrm{a}}$ & $\pm 0.14^{\mathrm{a}}$ \\
$\mathbf{5 \%}$ & 7.21 & 92.79 & 12.71 & 8.11 & 1.37 & 3.85 & 73.96 & 70.11 & 419.67 \\
$\mathbf{D C S F}$ & $\pm 0.17^{\mathrm{cd}}$ & $\pm 0.17^{\mathrm{bc}}$ & $\pm 0.11^{\mathrm{e}}$ & $\pm 0.12^{\mathrm{a}}$ & $\pm 0.15^{\mathrm{bc}}$ & $\pm 0.15^{\mathrm{d}}$ & $\pm 0.53^{\mathrm{b}}$ & $\pm 0.68^{\mathrm{b}}$ & $\pm 0.60^{\mathrm{c}}$ \\
$\mathbf{1 0 \%}$ & 7.89 & 92.11 & 13.51 & 8.12 & 1.75 & 5.79 & 70.83 & 65.04 & 410.44 \\
$\mathbf{D C S F}$ & $\pm 0.15^{\mathrm{b}}$ & $\pm 0.15^{\mathrm{d}}$ & $\pm 0.26^{\mathrm{c}}$ & $\pm 0.15^{\mathrm{a}}$ & $\pm 0.31^{\mathrm{ab}}$ & $\pm 0.28^{\mathrm{b}}$ & $\pm 1.00^{\mathrm{c}}$ & $\pm 1.28^{\mathrm{d}}$ & $\pm 1.61^{\mathrm{f}}$ \\
$\mathbf{1 5 \%}$ & 8.70 & 91.30 & 14.71 & 8.14 & 2.13 & 7.75 & 67.27 & 59.52 & 401.18 \\
$\mathbf{D C S F}$ & $\pm 0.23^{\mathrm{a}}$ & $\pm 0.23^{\mathrm{e}}$ & $\pm 0.13^{\mathrm{b}}$ & $\pm 0.27^{\mathrm{a}}$ & $\pm 0.13^{\mathrm{a}}$ & $\pm 0.32^{\mathrm{a}}$ & $\pm 0.85^{\mathrm{e}}$ & $\pm 1.17^{\mathrm{e}}$ & $\pm 0.45^{\mathrm{g}}$ \\
$\mathbf{5 \%}$ & 6.93 & 93.07 & 13.11 & 8.12 & 1.35 & 2.86 & 74.56 & 71.70 & 423.76 \\
$\mathbf{D M S F}$ & $\pm 0.12^{\mathrm{d}}$ & $\pm 0.12^{\mathrm{b}}$ & $\pm 0.15^{\mathrm{d}}$ & $\pm 0.19^{\mathrm{a}}$ & $\pm 0.28^{\mathrm{bc}}$ & $\pm 0.25^{\mathrm{e}}$ & $\pm 0.87^{\mathrm{b}}$ & $\pm 1.12^{\mathrm{b}}$ & $\pm 1.17^{\mathrm{b}}$ \\
$\mathbf{1 0 \%}$ & 7.35 & 92.65 & 14.80 & 8.09 & 1.74 & 3.81 & 71.56 & 67.75 & 418.25 \\
$\mathbf{D M S F}$ & $\pm 0.21^{\mathrm{c}}$ & $\pm 0.21^{\mathrm{c}}$ & $\pm 0.17^{\mathrm{b}}$ & $\pm 0.30^{\mathrm{a}}$ & $\pm 0.15^{\mathrm{ab}}$ & $\pm 0.17^{\mathrm{d}}$ & $\pm 0.79^{\mathrm{c}}$ & $\pm 0.96^{\mathrm{c}}$ & $\pm 0.22^{\mathrm{d}}$ \\
$\mathbf{1 5 \%}$ & 7.80 & 92.20 & 15.91 & 8.13 & 2.07 & 4.85 & 69.04 & 64.19 & 412.97 \\
$\mathbf{D M S F}$ & $\pm 0.27^{\mathrm{b}}$ & $\pm 0.27^{\mathrm{d}}$ & $\pm 0.30^{\mathrm{a}}$ & $\pm 0.25^{\mathrm{a}}$ & $\pm 0.21^{\mathrm{a}}$ & $\pm 0.11^{\mathrm{c}}$ & $\pm 0.87^{\mathrm{d}}$ & $\pm 0.98^{\mathrm{d}}$ & $\pm 0.03^{\mathrm{e}}$ \\
\hline
\end{tabular}

Each value was an average of three determinations.

Values followed by the same letter in columns are not significantly different at $\mathrm{p} \leq 0.05$.

Control: Wheat flour cookies, DCSF: defatted chia seeds flour DMSF: defatted moringa seeds flour.

T.C: Total carbohydrate A.C: Available Carbohydrates

On the other hand, it could be noticed that, there were no significant differences in ether extract contents of the control and substitution supplemented cookies. Ash content of cookies was ranged between $0.99 \%$ in control cookies to $2.13 \%$ in cookies substitution with $15 \%$ DCSF. There were no significant differences with higher value in the ash contents of the cookies substitution with 15\% DCSF and DMSF. Ash contents was decreased in the control but ash contents was increased significantly in sample which substitution with DCSF and DMSF. This increment may be due to incorporation of defatted chia and 
moringa seeds. Data of the present study are in agreement with those found by Ogunsina et al. (2011) and Mohammed (2019).

The data in the same Table revealed that, crude fiber contents of cookies substitution with different levels of DCSF and DMSF were higher than that of control sample. This might be due to the high fiber contents in DCSF and DMSF as compared to wheat flour. Fiber content increased from $1.90 \%$ in control to $7.75 \%$ in cookies with $15 \%$ DCSF. The variation in crude fiber content between control sample and substitution cookies with 5,10 and 15\% DCSF is high different significant. This is due to DCSF contained up to $40 \%$ crud fiber.

On the other hand, the Total carbohydrate content in cookies samples was significantly decreasing by increasing DCSF and DMSF. It was decreased from $77.41 \%$ in control to $67.27 \%$ and $69.04 \%$ in cookies substitution with $15 \%$ DCSF and DMSF. This is may be due to DCSF and DMSF are rich in protein and crude fiber. Furthermore, energy value of cookies samples was significantly decreasing by increasing DCSF and DMSF. It was decreased from $428.94 \mathrm{kcal} / 100 \mathrm{~g}$ in control to $401.18 \mathrm{kcal} / 100 \mathrm{~g}$ in cookies substitution with $15 \%$ defatted chia seeds. These results were in agreement with Ogunsina et al. (2011) who found that, cookies supplemented with moringa seeds powder were more nutritious than the control. The cookies supplemented with moringa seeds had more protein, fat, iron and calcium than control.

\subsection{Sensory characteristics of cookies substitution with different levels of defatted chia and moringa seeds flour:}

The data pertaining to sensory evaluation of cookies substitution with DCSF and DCMF were presented in Table (8). The higher score of taste was recorded in control cookies (9) followed by substitution cookies with 5\% DCSF and DCMF. The lowest score of taste was found in cookies substitution with 15\% DCMF (7.3). This may able due to the tasted bitter of defatted moringa seeds and rated as decrease acceptable by panelists (Ogunsina et al., 2011).

The color of any kind of food is an important parameter which gives the first sight impression on consumers and effects on its acceptability (Caudillo et al., 2008). From the results in this Table, it could be noticed that, significant differences were noticed in color score among control sample and substitution cookies with DCSF and DMSF. The lowest score of color was (7.5) and (7.6) in supplemented cookies with 15\% DMSF and DCSF, respectively. Apparent also from the same Table that, there were significant differences were noticed in odor score among control sample and substitution cookies with DCSF and DCMF. The highest score for odor was recorded in control cookies (9.5) and cookies supplemented with 5\% DCSF (9.3) and moringa seeds (8.9). Meanwhile, the lowest score of odor was found in cookies substitution with $15 \%$ of defatted chia (7.2) and moringa seeds (7.8).

Table 8: sensory characteristics of cookies supplemented with different levels of defatted chia and moringa seeds flour.

\begin{tabular}{lccccc}
\hline \multicolumn{1}{c}{ Parameters } & Taste & Color & Odor & Texture & $\begin{array}{c}\text { Overall } \\
\text { acceptability }\end{array}$ \\
\hline Control & $9.0 \pm 0.21^{\mathrm{a}}$ & $9.0 \pm 0.23^{\mathrm{a}}$ & $9.5 \pm 0.25^{\mathrm{a}}$ & $9.8 \pm 0.29^{\mathrm{a}}$ & $9.5 \pm 0.26^{\mathrm{a}}$ \\
$\mathbf{5 \%}$ DCSF & $8.3 \pm 0.32^{\mathrm{b}}$ & $8.5 \pm 0.35^{\mathrm{abc}}$ & $9.3 \pm 0.30^{\mathrm{a}}$ & $9.3 \pm 0.44^{\mathrm{ab}}$ & $8.9 \pm 0.36^{\mathrm{b}}$ \\
$\mathbf{1 0 \%}$ DCSF & $8.1 \pm 0.35^{\mathrm{bc}}$ & $7.9 \pm 0.43^{\mathrm{cde}}$ & $8.4 \pm 0.34^{\mathrm{b}}$ & $8.5 \pm 0.37^{\mathrm{cd}}$ & $8.6 \pm 0.30^{\mathrm{b}}$ \\
$\mathbf{1 5 \%}$ DCSF & $7.7 \pm 0.29^{\mathrm{cd}}$ & $7.5 \pm 0.37^{\mathrm{e}}$ & $7.2 \pm 0.25^{\mathrm{d}}$ & $7.2 \pm 0.42^{\mathrm{e}}$ & $7.5 \pm 0.41^{\mathrm{cd}}$ \\
$\mathbf{5 \%}$ DMSF & $8.4 \pm 0.35^{\mathrm{b}}$ & $8.7 \pm 0.39^{\mathrm{ab}}$ & $8.9 \pm 0.41^{\mathrm{ab}}$ & $9.1 \pm 0.33^{\mathrm{bc}}$ & $8.8 \pm 0.25^{\mathrm{b}}$ \\
$\mathbf{1 0 \%}$ DMSF & $7.9 \pm 0.40^{\mathrm{bc}}$ & $8.2 \pm 0.31^{\mathrm{bcd}}$ & $8.6 \pm 0.37^{\mathrm{b}}$ & $8.3 \pm 0.31^{\mathrm{d}}$ & $8.0 \pm 0.25^{\mathrm{c}}$ \\
$\mathbf{1 5 \%}$ DMSF & $7.3 \pm 0.25^{\mathrm{d}}$ & $7.6 \pm 0.25^{\mathrm{e}}$ & $7.8 \pm 0.35^{\mathrm{c}}$ & $7.0 \pm 0.40^{\mathrm{e}}$ & $7.3 \pm 0.21^{\mathrm{d}}$ \\
\hline
\end{tabular}

Values followed by the same letter in columns are not significantly different at $\mathrm{p} \leq 0.05$.

Control: Wheat flour cookies, DCSF: defatted chia seeds flour DMSF: defatted moringa seeds flour.

From the same Table, it could be observed that, there was no significant difference in texture between control sample and supplemented cookies with $5 \%$ of defatted chia. Meanwhile, significant differences were noticed in texture score among substitution cookies with defatted moringa and chia seeds. Also, from the same Table that, significant differences were noticed in overall acceptability score among control sample and substitution cookies DCSF and DMSF. The lowest overall acceptability score was found in cookies substitution with $15 \%$ of DCSF and DMSF. All samples were acceptability. These results were in agreement with Ogunsina et al. (2011); Divyashree et al. (2016); Mesias et 
al.(2016); Goyat et al. (2018)and Chelladurailet al .(2019) they reported that, the incorporation of wheat flour with increasing levels of debittered Moringa oleifera seed powder meant the surface cracking pattern, crumb color, texture, mouth feel and flavor reduced.

\section{References}

Abdulkarim, S.M., Long, K., O.M. Lai, S.K.S. Muhammad, and H.M. Ghazali, 2005. Some physicchemical properties of Moringa oleifera seed oil extracted using solvent and aqueous enzymatic methods. Food Chemistry, 93: 253-263.

Abiodun, O.A., J.A. Adegbite, and A.O. Omolola, 2012. Chemical and physicochemical properties of moringa flours and oil Global J. of Sci. Frontier Res., Biological Sci., 12 (5): 12-7.

Afify, A.E.M.M., H.S. El-Beltagi, S.M. Abd El-Salam, and A.A. Omran, 2012. Biochemical changes in phenols, flavonoids, tannins, vitamin $\mathrm{E}, \beta$-carotene and antioxidant activity during soaking of three white sorghum varieties. Asian Pacific J. of Tropical Biomedicine, 2(3) : 203-209.

Alobo, A.P., 2001. Effect of sesame seed flour on millet biscuit Characteristics. Plant Foods for Human Nutrition, 56: 195-202.

Alsmeyer, R.H., A.E. Cunningham, and M.L. Happich, 1974. Equation to predict protein efficiency ratio (PER) from amino acid analysis. Food Tech., (28):34- 38.

Alvarado, J. and J. Aguilera, 2001. Metodos para medir propiedades fisicas en industrial de alimentos. Ed. Acri-bia. Zaragoza, Espana,15: 347-348.

Amato, M., M.C. Caruso, F. Guzzo, F. Galgano, M. Commisso, R. Bochicchio, and F. Favati, 2015. Nutritional quality of seeds and leaf metabolites of chia (Salvia hispanica L.) from southern Italy. European Food Res. and Tech., 241:615-625.

Anwar, F., S.N. Zafar, and U. Rashid, 2006. Characterization of moringa seed oil from drought and irrigated regions of Punjab. J. of Food Science, 57(2): 160-168.

Arshad, M., F. Anjum, and T. Zahoor, 2007. Nutritional assessment of cookies supplemented with defatted wheat germ. Food Chem., 102: 123e-128.

A.O.A.C. 2005. Association of Official of Analytical Chemists, Official Methods of Analysis. 18th Ed., Pub. By the A.O.A.C., Arlington, Virginia, 2220 USA.

Barrientos, V.A., A. Aguirre, and R. Borneo, 2012. Chia (Salvia hispanica) can be used to manufacture sugar-snap cookies with an improved nutritional value. International J. of Food Studies, 1(2).

Blauth, O.J., M. Charezinski, and H. Borbec, 1963. A new rapid method for determining tryptophan, Analytical Biochemistry, 6: 67-70.

Capitani, M.I., V. Spotorno, S.M. Nolasco, and M.C. Tomas, 2012. Physicochemical and functional characterization of by-products from chia (Salvia hispanica, L.) seeds of Argentina LWT-Food Science and Technology, 45(1):94-102.

Chelladurai, C., A.A. Pandey, S.A. Panmand, and S. Nikam, 2019. Development of innovative bakery product chia seed enriched cookies. Development, 4 (2).

Chinma, C.E., B.S. Ogunsina, L. Latta, and T. Chukwu, 2013. Effects of germination on the chemical, functional and pasting properties of flour from moringa seed. Nigerian Food J., 27: 102-106.

Codex Alimentarius Stan 210, 2003. Norma del CODEX para Aceites Vegetales Especificados.

Craig, R., and M. Sons, 2004. Application for approval of whole chia (Salvia hispanica L.) seed and ground whole chia as novel food ingredients. Advisory committee for novel foods and processes. Ireland: Company David Armstrong, 1: 1-29.

Divya, M., 2012. Biscuit industry in India - an overview.

Divyashree, K.A., G.K. Sharma, A.D. Semwal, and U. Mesha. 2016 Development and storage stability of buckwheat-chia seeds fortified biscuits. International J. of Food Fermentation Tech., 6(1):95106.

El-Massry, F.H., M.E.M. Mossa, and S.M. Youssef, 2013. Moringa oleifera plant" Value and utilization in food processing”. Egypt. J. Agric. Res., 91(4): 1597-1609.

European Food Safety Authority EFSA. 2009. Scientific Opinion of the Panel on Dietetic Products Nutrition and Allergies on a- Reqest from the European Commission on the Safety of Chia Seed (Salvia hispanica L.) and ground Whole Chia Seed as a Food Ingredient. EFSA.J.996:1-2.

FAO/WHO, Food and Agriculture Organization and World and Health Organization, 1973. Energy and protein requirements, WHO Tech. Rept., Series No. 522. Geneva. 
Farag, S.A., A. El-Shirbeeny and E.N. Ashga, 1996. Physicochemical studies for preparing quickcooking rice by using gamma irradiation. Annals of Agric. Sci., Moshtohor, 34: 641-652.

Farahat, G.A., H.B. Ekram and M.A. El-Bana, 2020. Effects of late wilt disease on infection development of ear rot disease, phenoliccompounds, trypsin and $\alpha$-amylase inhibitors of some maize hybrids grains andquality characteristics of fortified cookies.Middle East J. Agric. Res., 9(3): 515-532.

Fernandes, S.S. and M.D.L.M. Salas-Mellado, 2017. Addition of chia seed mucilage for reduction of fat content in bread and cakes. Food Chem., 227: 237-244.

Fitriana, W.D., T. Ersam, K. Shimizu, and S. Fatmawati, 2016. Antioxidant activity of Moringa oleifera extracts. Indonesian J.of Chem., 16(3) : 297-301

Giaretta, D., V.A. Lima, and S.T. Carpes, 2018. Improvement of fatty acid profile in breads supplemented with Kinako flour and chia seed. Innovative Food Sci. and Emerging Tech., 49: 211-214.

Gopalakrishnanb, L., K. Doriyaa, and D.S. Kumara, 2016. Moringa oleifera: a review on nutritive importance and its medicinal application. Food Sci. Human Wellness, 5: 49-56.

Goyat, J., S.J. Passi, S. Suri, and H. Dutta, 2018. Development of chia (Salvia hispanica, L.) and quinoa (Chenopodium quinoa, L.) seed flour substituted cookies-physicochemical, nutritional and storage studies. Current Research in Nutrition and Food Sci. J., 6(3) : 757-769.

Hammad, E.M., 2018. Properties of Processed Moringa Kernels and their Effect on som Bakery Products. Phd Thesis. Food Science and Technology Department. Faculty of Home Economics. Al-Azhar University, Al-Azhar, Egypt.

Ixtaina, V.Y., S.M. Nolasco, and M.C. Tomas, 2008. Physical properties of chia (Salvia hispanica L.) seeds. Industrial Crops and Products. 28:286-293.

Ixtaina, V.Y., S.M. Nolasco, and M.C. Toma's, 2012. Oxidative stability of chia (Salvia hispanica L).seed oil: effect of antioxidants and storage conditions. J. Am. Chem. Soc., 89:1077-109.

James, C.S., 1995. Analytical Chemistry of Foods, Published by Blacki Academic and Professional, an Imprint of Chapman and Hall, Wester Cleddens Road, Bishopbriggs, Glasgow G 642 NZ.

Kahlon, T., F. Chow, R. Sayre and A. Betschart, 1992. Cholesterol-lowering in hamsters fed rice bran at various levels, defatted rice bran and rice bran oil. J. Nut., 122: 513-519.

Kasolo, J., G. Bimenya, and L. Ojok, 2010: Phytochemicals and uses of Moringa oleifera leaves in Ugandan rural communities. J. Med Plants Res., 4: 753-577.

Kulczyński, B., J. Kobus-Cisowska, M. Taczanowski, D. Kmiecik, and A. Gramza-Michałowska, 2019. The chemical composition and nutritional value of chia seeds-Current state of knowledge. Nutrients, 11(6): 1242.

Lee, S.C., J.H. Kim, K.C. Nam, and D.U. Ahn, 2003. Antioxidant properties of far infrared-treated rice hull extract in irradiated raw and cooked turkey breast. J. Food Sci., 68: 1904-1909.

Mamat, H., M. Abu-Hardan, and S. Hill, 2010. Physicochemical properties of commercial semi-sweet biscuit. Food Chem., 121(4): 1029-1038.

Marineli, R.D., E.A. Moraes, S.A. Lenquiste, A.T. Godoy, M. N. Eberlin, M.R. Marostica, 2014. Chemical characterization and antioxidant potential of Chilean chia seeds and oil (S. hispanica L.). Lwt-Food Sci. and Tech., 59(2): 1304-1310.

Masih, L.P., S. Singh, S. Elamathi, P. Anandhi, and T. Abraham, 2019. Moringa: A multipurpose potential crop-A review. In Proc Indian Natn Sci Acad., 85(3): 589-601.

Mesias, M., F. Holgado, G. Marquez-Ruiz, and F.J. Morales, 2016. Risk/benefit considerations of a new formulation of wheat- based biscuit supplemented with different amounts of chia flour. Food Sci. and Tech., 73:528-535

Mohammed, O.B., A. El-Razek, A. Mohamed, M.H. Bekhet, and Y.G.E.D. Moharram, 2019. Evaluation of Egyptian Chia (Salvia hispanica L.) Seeds, Oil and Mucilage as Novel Food Ingredients. Egyptian J. of Food Sci., 47(1): 11-26.

Mohdaly, A., M.A. Sarhan, I. Smetanska and A. Mahmoud, 2010. Antioxidant properties of various solvent extracts of potato peels, sugar beet pulp, and sesame cake. J. of the Sci. of Food and Agric., 90: 218-226.

MuneMune, M.A., S.R. Minka, L. I. Mbome, and F. X. Etoa, 2011. Nutritional potential of Bambara bean protein concentrate. Pakistan J. of Nutrition, 10: 112-119. 
Murphy, J. and J.P. Riley, 1962. A modified single solution method for determination of phosphate in natural waters, Anal. Chem. Acta., 27: 31-36.

National Academies of Sciences, Institute of Medicine, 2001. Fruits and vegetables yield less vitamin A than previously thought; upper limits set for daily intake of vitamin A and Nine Other Nutrients, Press Release Jan. 9.

Ogunsina, B.S., C. Radha, and R.S. Govardhan Singh, 2010. Physicochemical and functional properties of full-fat and defatted Moringa oleifera kernel flour. International j. of food sci. and tech., 45(11) : 2433-2439

Ogunsina, B.S., R. Cheruppanpullil, and I. Dasappa, 2011. Quality characteristics of bread and cookies enriched with debittered Moringa oleifera seed flour . International J. of Food Sci. and Nutrition, 62(2):185-194.

Olosunde, O.O., O.A. Abiodun, A.A. Amanyunose, and A.B. Adepeju 2014. Sensory and nutritional characteristics of kununzaki enriched with moringa (Moringa oleifera) seed flour. Amer. J. of Experimental Agric., 4(9):1027.

Olushola, A.T.E., 2006. The Miracle Tree, Moringa oleifera (Drumstick). In: Achieve Vibrant Health with Nature, Keep Hope Alive Series 1, Unijos Consultancy Limited.

Pearson, D., 1976. The Chemical Analysis of Foods, $7^{\text {th }}$ Ed. Churchill, London, U.K.

Peiretti, P.G., and F. Gai, 2009. Fatty acid andnutritive quality of chia (Salvia hispanica L.) seeds and plant during growth. Animal Feed Sci. and Tech., 148 (2-4): 267-275.

Pereira, F.S., C.C. Galvão, V.F. de Lima, M.F. da Rocha, A.R. Schuler, V.L. da Silva, and N.M. de Lima Filho, 2016. The versatility of the Moringa oleifera oil in sustainable applications. OCL, 23(6): A601.

Pellett, P.L. and V.R. Young, 1980. Nutritional evaluation of protein foods, Food and Nutrition Bulletin Supplement, 4- United Nations Univ., Japan.

Reyes-Caudillo, E., A. Tecante, and M.A. Valdivia-Lopez, 2008. Dietary fiber content and antioxidant activity of phenolic compounds present in Mexican chia (Salvia hispanica L.) seeds. Food Chem., 107:656-663.

Rodrigo, R., J. Gonzalez and F. Paoletto 2011. The role of oxidative stress in the pathophysiology of hypertension. Hypertens Res., 34 431-40.

Saad, M.K., 2015. Comparison of Moringa oleifera seed oil characterization produced by chemical and mechanical method (Doctoral dissertation, Universiti Malaysla Pahang).

Sadasivam, S. and A. Manickam, 1992. Determination of total sugars, reducing sugars and amino acids, Agriculture Science, Wiley Eastern Limited, New Delhi, pp. 6 and 40, India.

Salama, M.A., 2019. Studies on Moringa (Moringa oleifera) Seeds and Their Uses in Human Nutrition. Phd Thesis. Food Technology Department. Faculty of Agriculture Kafrelsheikh. Kafrelsheikh University, Kafrelsheikh, Egypt.

Salha, S.M., 2018. Nutritional and Therapeutic Effects of Chia (Salvia hispanica L.) and Quinoa Seeds (Chenopodium quinoa) on Obesity and Diabetes Mellitus in Albino Rats. Phd Thesis. Home Economics Department. Faculty of Specific Education.Tanta University, Tanta, Egypt.

Scalbert, A., C. Manach, C. Morand, C. Rémésy, L. Jiménez, 2005. Dietary Polyphenols and the Prevention of Diseases. Critical Reviews in Food Sci. and Nutrition, 45(4): 287-306

Segura-Campos, M.R., N. Ciau-Solis, G. Rosado-Rubio, L/ Chel-Guerrero, and D. Betancur-Ancona, 2014. Physicochemical characterization of chia (Salvia hispanica, L.) seed oil from Yucatan, Mexico. Agric. Sci., 5:220-226.

Singleton, V.L., R. Orthofer, and R.M. Lamuela-Raventos, 1999. Analysis of total phenols and other oxidation substrates and antioxidants by means of Folin-Ciocalteu reagent. Methods Enzymol. 299: 152-178.

Stahl, E., 1967. Thin Layer Chromatography. A laboratory hand book. Ed., Springer Verloag, Berline P. 359, Heidel Berg, New York.

Steel, R.G. and J.H. Torrie, 1980. Principles and procedures of statistics. $2^{\text {nd }}$ Ed. pp 120. McGraw-Hill, New York, USA.

Su, L., J.-J. Yin, D. Charles, K. Zhou, J. Moore, and L. Yu, 2007. Total phenolic contents, chelatingcapacities, and radical-scavenging properties of blackpeppercorn, nutmeg, rosehip, cinnamon and oreganoleaf. Food Chem., 100:990-997. 
Timilsena, Y.P., J. Vongsvivut, R. Adhikari, and B. Adhikari, 2017. Physicochemical and thermal characteristics of Australian chia seed oil. Food Chem., 228:394-402.

Ullah, R., M. Nadeem, A. Khalique, M. Imran, S. Mehmood, A. Javid, and J. Hussain, 2015. Nutritional and Therapeutic Perspectives of Chia (Salvia hispanica L.): a Review. J. of Food Sci. and Techn. Published online :01 October 2015 in Springer. DOI 10.1007/s13197-015-1967-0

Vibhute, S., V. Kasture, S. Kasture, P. Kendre, S. Rupnar, and V. Pande, 2015. Design and characterization of Moringa oleifera seed oil impregnated anti-inflammatory topical microdispersion

Vuksan, V., A.L. Jenkins, C. Brissette, L. Choleva, E. Jovanovski, A.L. Gibbs, R.P. Bazinet, F. AuYeung, A. Zurbau, H.V.T. Ho, and L. Duvnjak, 2017. Salba-chia (Salvia hispanica, L.) in the treatment of overweight and obese patients with type 2 diabetes: A double-blind randomized controlled trial. Nutrition, Metabolism and Cardiovascular Diseases, 27(2): 138-146.

Watts, B.M., G.L. Ylimaki, L.E. Jeffery, and L.G. Elias, 1989. Basic Sensory Methods for Food Evaluation. IDRC, Ottawa, Ontario, Canada, 66-78. 